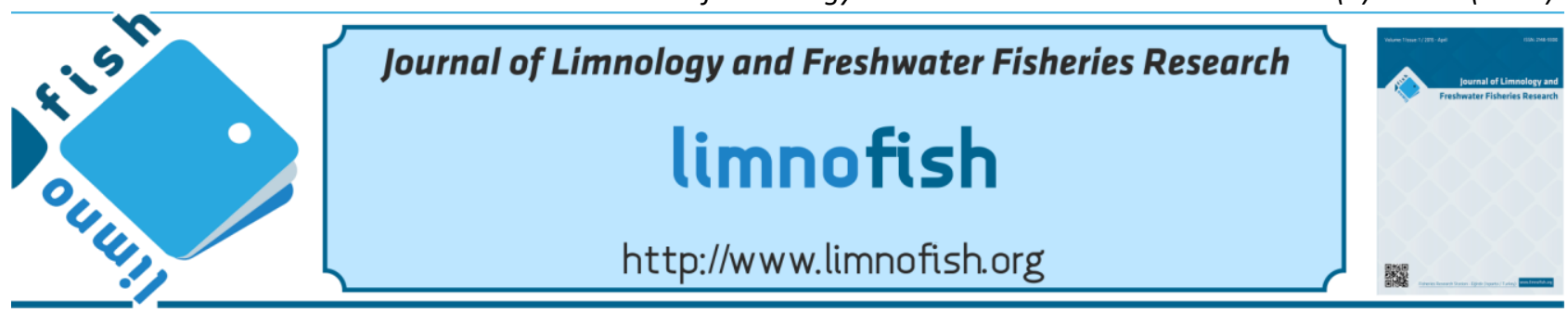

\title{
Assessment of Fish Exports from Blantyre District, Southern Malawi
}

\author{
Langson SAMALA* iD Fanuel KAPUTE iD \\ Department of Fisheries \& Aquatic Sciences, Mzuzu University, Private Bag 201, Mzuzu 2, Malawi
}

\section{A B S TRACT}

This study presents findings on fish exports from Blantyre, which is the biggest commercial city in Malawi. A cross-sectional research design was used in the study in which fish quantities, species, processing methods, gender of fish exporters and export destinations were analysed. Non-probability data collection methods were used on the secondary data that was collected from Blantyre District Fisheries Office. Findings indicate that a total of $9596 \mathrm{~kg}$ (9.6 metric tonnes) of fish was exported within a period of six months in the year 2013 comprising all species available in the local markets and those endemic in Malawi's water bodies. Most fish were exported as sun-dried, para-boiled and smoked. Findings suggest that fish exports from Malawi are in their infancy, fluctuate, and are insignificant for making a positive and sustainable impact to the economy of the country. It is recommended that national and regional policies should be fully utilized to curb exports of fish in order to sustainably satisfy the local huge demand for fish. About $82.6 \%$ of the fish exporters were women underpinning the need for policy considerations that value their critical role in the fish export trade such as women empowerment.

\section{ARTICLE INFO}

$\begin{array}{ll}\text { SHORT COMMUNICATION } \\ \text { Received } & : 20.02 .2018 \\ \text { Revised } & : 08.08 .2018 \\ \text { Accepted } & : 06.09 .2018 \\ \text { Published } & : 25.04 .2019\end{array}$

DOI:10.17216/LimnoFish.397020

\section{* CORRESPONDING AUTHOR}

langsonsamala88@gmail.com

Phone : +265995388420

Keywords: Fish exports, species, processing, destinations, gender

How to Cite

Samala L, Kapute F. 2019. Assessment of Fish Exports from Blantyre District, Southern Malawi. LimnoFish. 5(1): $70-75$. doi: 10.17216/LimnoFish.397020

\section{Introduction}

In Malawi, documented fish exports are estimated at 0.102 metric tonnes, accounting for a monetary value of MWK (Malawi Kwacha currency) 22,000 (US\$ 250) in 1998 to 159.5 metric tonnes valued at MWK18.5 million (US\$170,000) in 2002 (Commonwealth/GTZ 2007). The figures indicate that fish exports increased in the period of 1998 to 2002. However, the Government of Malawi (GoM 2012) reported that annually, an average of 86 tonnes of fish was exported between 2002 and 2010. Reports also indicated that quantities of annual fish exports within the same period greatly fluctuated due to dwindling fish harvests (Commonwealth/GTZ 2007; Donda and Njaya 2007; GoM 2011, 2012). Fish catches from Malawi were estimated at 70000 and 3000 metric tonnes per annum from capture fisheries and fish farming, respectively (GoM 2012). To the contrary, the domestic demand for fish in the country was estimated at around 110000 metric tonnes per year (GoM 2012) indicative of a supply deficit. Recent reports showed that Malawi informally exported fish to neighbouring Tanzania, Mozambique and Zambia between 2015 and 2016 with an estimated annual quantity of 24115.68 metric tonnes valued at 41.6 million dollars (Mussa et al. 2017). Such reports exist at a time when the country was in a dire shortage of fish supply with an average per capita annual fish consumption estimated at 5.6 $\mathrm{kg}$, far below the 13-15 kg recommended by the World Health Organisation (Kapute 2017). The demand for fish in Malawi has in recent years tremendously increased due to increased population against the declining fish catches from the natural waters. In Malawi, fish provides the best and most affordable source of dietary animal protein to many people contributing about $28 \%$ of all dietary animal protein supply (Kapute 2017). Another concern is that there is little consideration about quality standards for fish trade in Malawi and clearly indicating that fish quality standards have not been well developed for exports to highly regulated markets (Kapute 2009; GoM 2012; ManyungwaPasani et al. 2017). The traders have thus, been 
trading without proper licensing and no empowerment. In addition, there have been limited studies focusing on the exports of fish from Malawi. This study differs from earlier studies because it focuses on formal fish exports. The novelty of this study provides a foundation to the sustainability of the fish exports in order for the country to benefit from the trade and diversify the income generating activities in the fisheries value chain. In this study, exports of fish from Malawi were assessed in order to assist the government in establishing the magnitude of fish quantities exported, fish processing methods, fish species, gender of exporters and fish export destinations.

\section{Material and Methods \\ Study area and data collection}

Cross-sectional research design was used in the study (Bhattacherjee 2012) and fish export data were collected from Blantyre District Fisheries Office in southern Malawi. Blantyre is the commercial and industrial city of Malawi and forms the communication and transportation hub to all parts of the country as well as the neighbouring countries. Fish exports data are collected by the Malawi Department of Fisheries when issuing the phytosanitary certificates to fish exporters. Information that is contained in the phyto-sanitary certificates includes destinations, fisheries quality control unit, name and address of exporter, declared name and address of consignee, declared quality and name of fish product, scientific name of fish, number and description of packages, declared means of conveyance and treatment, among others. The Department of Fisheries started providing the phytosanitary certificates to Blantyre District Fisheries Office in March 2013. To ensure validity and reliability of the data collected, 10 duplicate sanitary certificates were collected from Blantyre District Fisheries Office before the actual data collection exercise. The collected duplicate Phyto-sanitary certificates were checked by qualified technical personnel in the Department of Fisheries and Aquatic Sciences at Mzuzu University, Malawi. Fish exports data for a period of six months, from May to October, 2013 were collected from a total of 217 individual traders using non - probability sampling technique i.e. all the data available were collected for the study (Ukaonu et al. 2011; Haambiya et al. 2013).

\section{Species and quantity of fish exported}

Fish species that an individual person could export were summarized as percentages instead of listing used in earlier studies (Jayalal and Ramachandran
2012). Data collected for this study did not indicate the exact quantities exported per species and as such, frequencies were used. The monthly fish exports were added for all months from May to October 2013, and quantities were also added to give a total quantity of fish exported within the period of study. The number of fish exporters were separately classified into three categories according to the quantity of fish exported and percentages of monthly quantities from total quantity exported were computed. The classes were: less than $50 \mathrm{~kg}$ (fq $<50 \mathrm{~kg})$, between 50 and $100 \mathrm{~kg}(50<\mathrm{fq}<100)$, and greater than $100 \mathrm{~kg}$ ( $\mathrm{fq}>100)$, where $\mathrm{fq}$ is the fish quantity exported. The percentage of traders in each category was calculated. To determine fish processing methods used for fish destined for trading in the international markets, the proportion of each processed method of the fish species was summarized in the bar graphs to observe the frequently exported forms of processed fish.

\section{Gender of fish exporters and destinations of fish exports}

The percentages of male and female fish exporters were found for each month of the study to understand whether they were equal percentages for each month. All countries, which serve as markets for fish from Blantyre, were identified and frequencies of fish traders were calculated and recorded. This method was preferred due to its robustness in encompassing specific details without overlooking the importance of the details.

\section{Statistical analysis}

Data were analyzed in SPSS Software version 16.0. Chi - square (goodness of fit) test was used to test for the differences in the distributions of categories of fish exporters and their gender. The hypotheses were tested at 5\% significance level. Graphs were generated using Microsoft Excel 2010.

\section{Results}

\section{Quantity of fish exports}

A total of $9596 \mathrm{~kg}$ of fish were exported in the period studied and the highest quantity was exported in the month of June (39.2\%). It should be noted that although the percentages of fish exported per month were fluctuating, the trend showed an increase from $7.9 \%, 12.0 \%$ and $17.5 \%$ from July, August and September respectively (Figure 1).

There were significant differences among the three categories of fish exporters in all the months studied (Table 1). The months showing the degrees of freedom (df) of one suggest no fish exports of more than $100 \mathrm{~kg}$. 


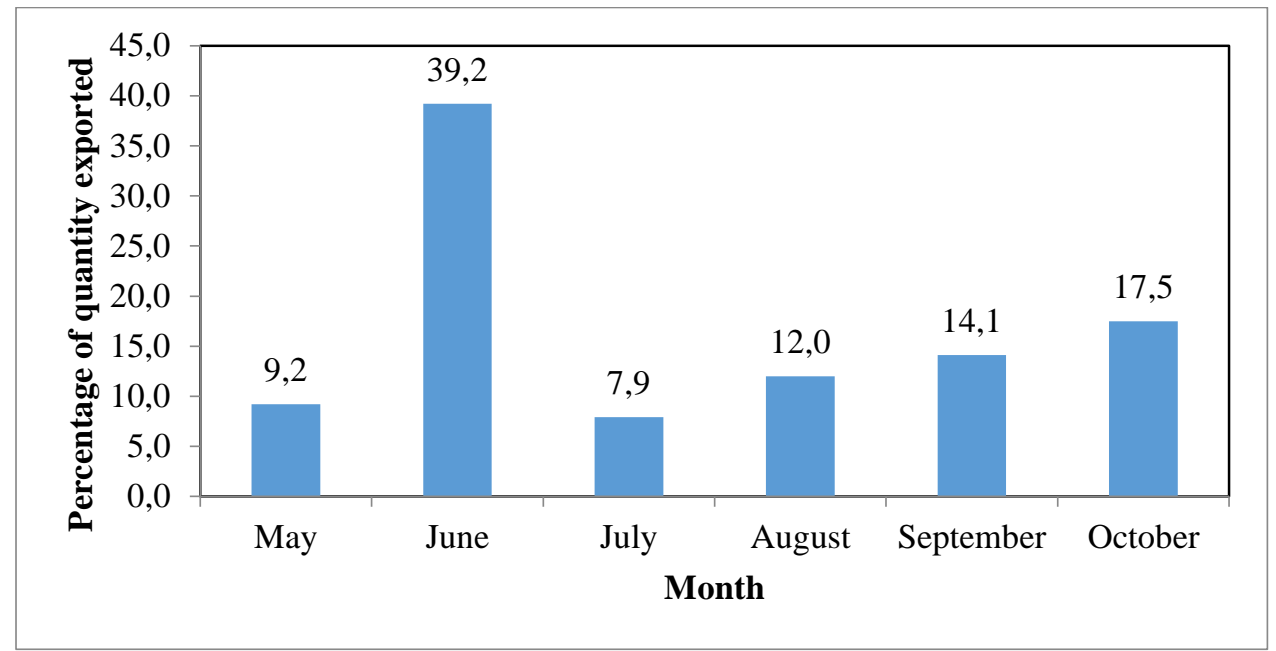

Figure 1. Percentage of fish exports from May to October 2013 from Blantyre

Table 1. Chi-square (goodness of fit) test results for the three categorised fish exporters

\begin{tabular}{ccccccc} 
& May & June & July & August & September & October \\
\cline { 2 - 6 }$\chi^{2}-$ value & $13.300^{\mathrm{a}}$ & $28.374^{\mathrm{a}}$ & $4.263^{\mathrm{a}}$ & $9.143^{\mathrm{a}}$ & $11.789^{\mathrm{a}}$ & $12.250^{\mathrm{a}}$ \\
df & 2 & 1 & 1 & 1 & 2 & 2 \\
Asymp. Sig. & 0.001 & 0.000 & 0.039 & 0.002 & 0.003 & 0.002
\end{tabular}

Values with similar superscripts in a row are significantly different $(\mathrm{P}<0.05)$.

Fish species on international trade

Fish species that were exported are Engraulicypris sardella (Günther, 1868) (local name: Usipa), Clarias gariepinus (Burchell, 1822) (Catfish: Mlamba), Oreochromis species (Weyl et al 2010) (Chambo), Oreochromis mossambicus
(Makakana),

Enteromius

paludinosus

(Peters, 1852) (Matemba), and Rhamphochromis species (Mcheni). However, frequently exported species were $E$. sardella and $C$. gariepinus with more than $75 \%$ and $65 \%$ of the fish exporters respectively (Figure 2).

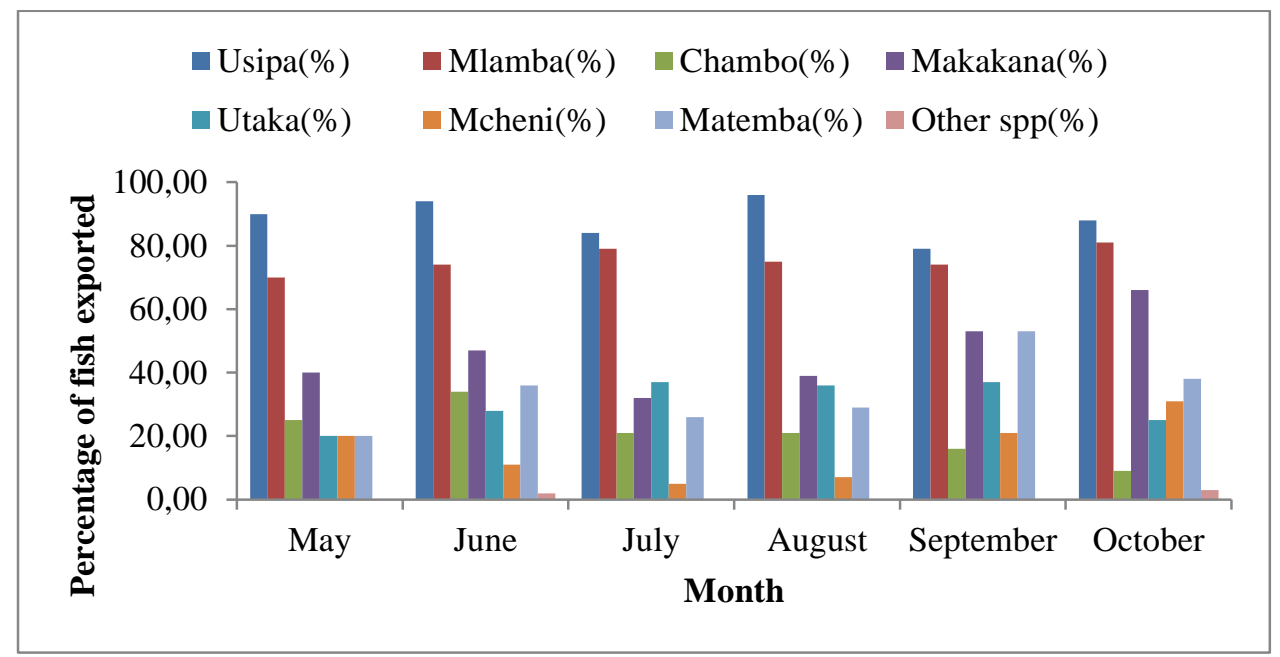

Figure 2. Percentages of fish exporters from Blantyre to various export destinations from May to October, 2013.

\section{Fish processing methods}

Observed fish processing methods were sun - dried and para - boiling for E. sardella (Figure 3).

Commonly, Oreochromis species (local name: Chambo), Diplotaxodon spp. (Ndunduma) and C. garipinus (Catfish) were exported in smoked form. A small quantity of Oreochromis species were also exported frozen while Rhamphochromis species (Mcheni) were exported in the smoked form compared to other forms (Figure 4).

Fishes such as Barbus species (Matemba), Copadichromis species (Utaka), Bagrus species (Kampango), Buccochromis species (Mbaba) were mainly exported in smoked and sun - dried forms (Figure 5). 


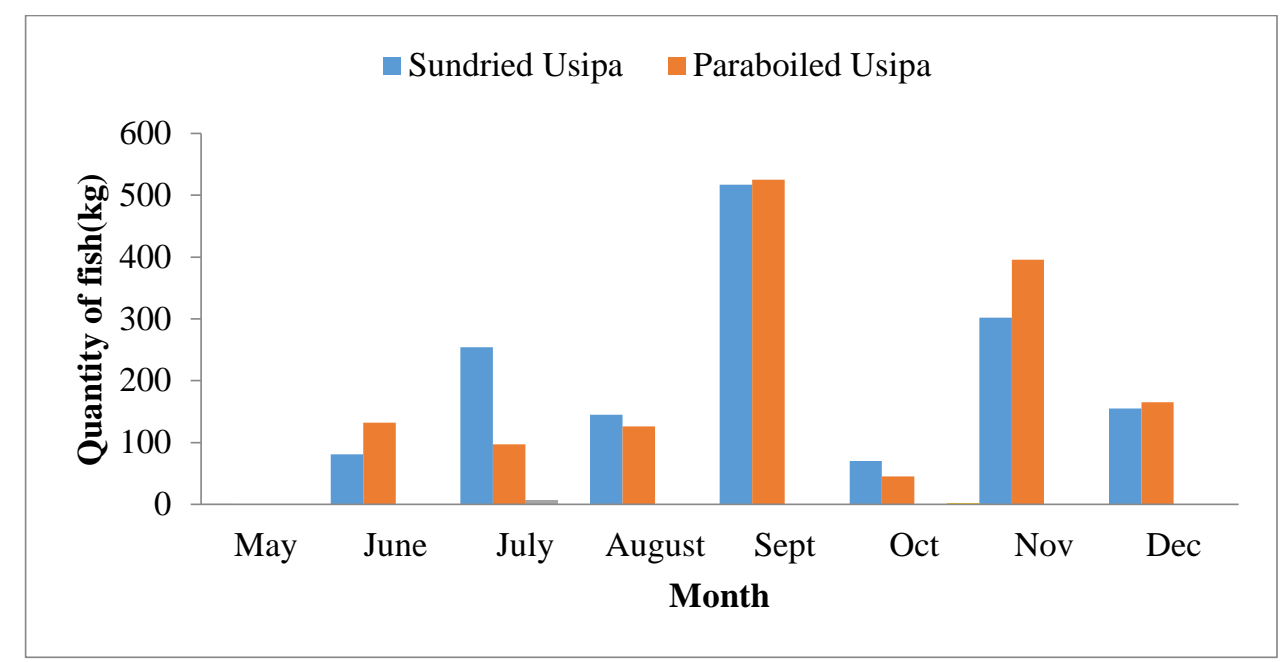

Figure 3. Processed form of exported E. sardella

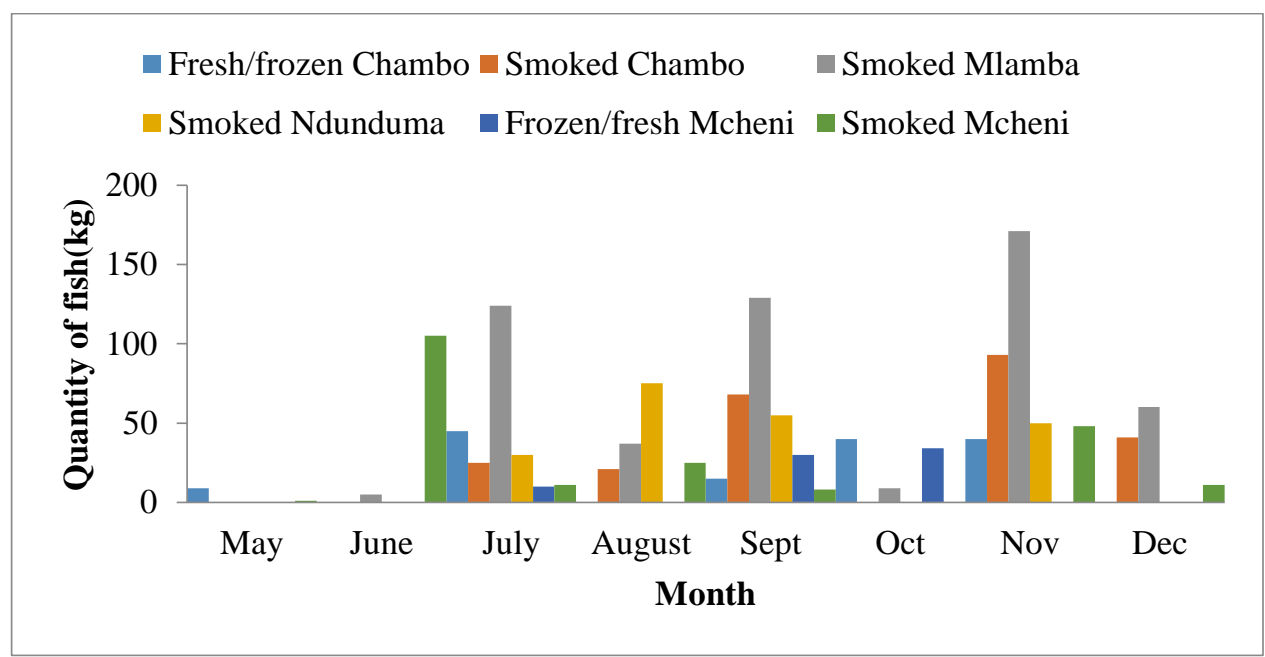

Figure 4. Processed form of Oreochromis spp. (Chambo), Diplotaxodon spp. (Ndunduma), Rhamphochromis spp. (Mcheni) and Clarias spp. (Catfish) exported from Blantyre.

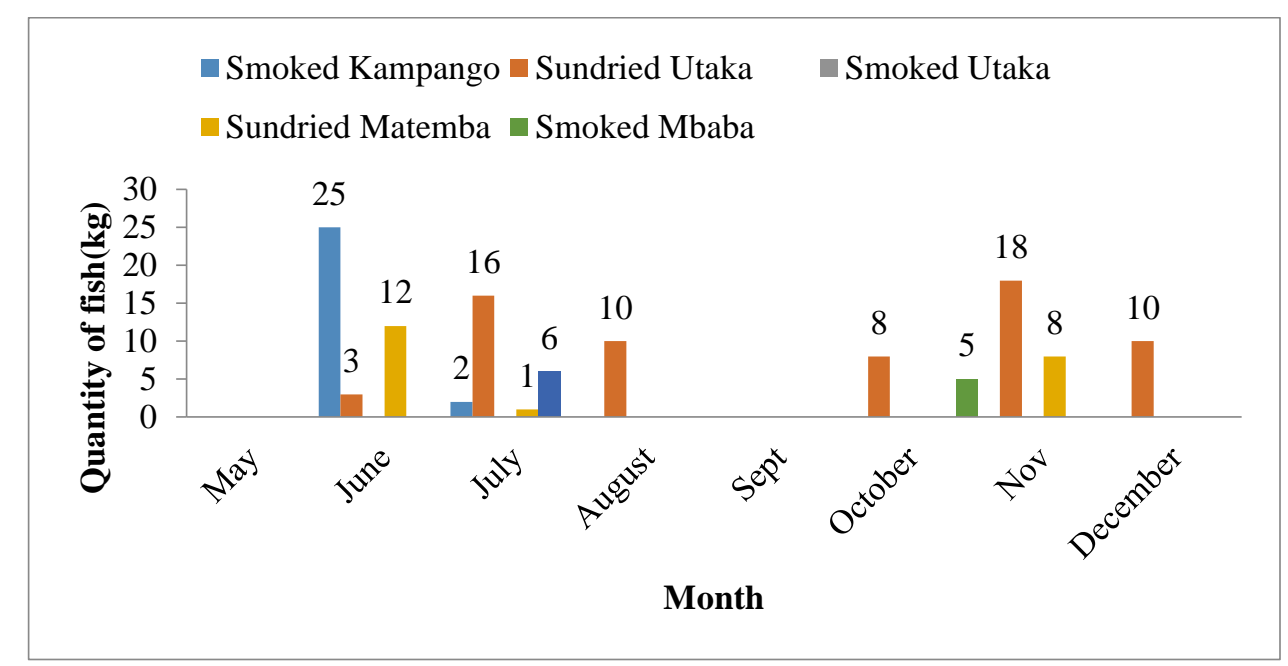

Figure 5. Processed form of Copadichromis spp. (Utaka), Enteriomius spp.(Matemba), Bagrus meridionalis (Kampango) and Buccochromis spp. (Mbaba) exported in 2013.

Export destinations of fish from Blantyre

Results show that the Republic of South Africa $(n=214)$ is the main importer of fish from Malawii.
Some fish were also exported to Botswana $(n=1)$, Mozambique $(n=1)$ and Vietnam $(n=1)$ in the same period. 
Contrary to the expectations, there was no export Zambia and Zimbabwe in the period under study of fish to the neighboring countries like Tanzania, (Table 2).

Table 2. Number of fish exporters from Blantyre in months of study

\begin{tabular}{cccc}
\hline Month & Republic of South Africa $(\mathbf{n = 2 1 4})$ & Botswana $(\mathbf{n = 1})$ & Other $(\mathbf{n = 2})$ \\
\hline May & 20 & 0 & 0 \\
June & 98 & 0 & 1 \\
July & 19 & 0 & 0 \\
August & 27 & 1 & 0 \\
September & 19 & 0 & 0 \\
October & 31 & 0 & 1 \\
\hline
\end{tabular}

\section{Gender of fish exporters}

About $13.8 \%$ of fish exporters were males and $86.2 \%$ were females with a significant difference $(\mathrm{P}<0.05)$ between the gender of fish exporters in the months of May $(\mathrm{P}=0.000$, June
$(\mathrm{P}=0.000)$, July $(\mathrm{P}=0.000)$, August $(\mathrm{P}=0.001)$ and October $(\mathrm{P}=0.000)$ and the month of September showed gender difference was insignificant $(\mathrm{P}=0.108)$ as reported in Table 3.

Table 2. Percentages and Chi - square (goodness of fit) test results for fish exporters.

\begin{tabular}{ccccc}
\hline Month & Male $(\%)$ & Female $(\%)$ & $\chi^{2}$-value & Asymp. Sig. \\
\hline May & 5.0 & 95.0 & $16.200^{\mathrm{a}}$ & 0.000 \\
June & 12.1 & 87.9 & $56.818^{\mathrm{a}}$ & 0.000 \\
July & 5.3 & 94.7 & $15.211^{\mathrm{a}}$ & 0.000 \\
August & 17.9 & 82.2 & $11.571^{\mathrm{a}}$ & 0.001 \\
September & 31.6 & 68.4 & $2.579^{\mathrm{b}}$ & 0.108 \\
October & 15.6 & 84.4 & $15.125^{\mathrm{a}}$ & 0.000 \\
\hline
\end{tabular}

\section{Discussion}

The study of fish exports from Blantyre District in Malawi was limited by the availability of sufficient data. Data that was available at the time of the study were for six months only. The findings in this study were consistent with earlier studies that fish quantities exported from Malawi have been low (Commonwealth/GTZ 2007; Donda and Njaya 2007; Kapute 2009; GoM 2011, 2012). Quantities as low as $9596 \mathrm{~kg}$ exported in six months from Blantyre District may imply that fish exports at the current rate cannot meaningfully contribute to the economy of the country. However, due to increased informal cross border trade as evidenced by the informal fish export of 24115.68 metric tonnes between 2015 and 2016 from Malawi to neighboring countries (Mussa et al. 2017), fish export quantities could be higher than reported. The inconsistences earlier reported by Kapute (2017) may rise due to poor monitoring of the fish exports by the Government of Malawi. The increasing trend of fish export quantities from May $(9.2 \%)$, July (7.9\%), August (12.0\%), September
$(14.1 \%)$ and October (17.5\%) may be indicative of increased fish availability on the markets following the opening of the lakes following seasonal closure in November and/or December to March. Highest fish exports $(39.2 \%)$ in June may be due to traders turning up as production of E. sardella increased along with other species. This study revealed that E. sardella and Copadichromis species which were commercially - less valuable fishes (GoM 2012; Singini 2013) were the mostly exported by traders (at least $75 \%$ of the traders exported the two species). The fish processing methods such as sun-drying, smoking and para-boiling indicate that the exported fishes were destined for local markets (Kapute 2009; GoM 2012). The processing methods also suggest that the species of fish exported are small in size.

It was observed fish were mainly exported to the Republic of South Africa as earlier reported by GoM (2011). Republic of South Africa imported largest quantities of fish from Malawi probably due to many Malawians staying in that country as consumer studies in Johannesburg found that demand for fish 
species depends on culturally acquired tastes (Kapute 2017). However, other studies have established reported fish exports to Zambia, Tanzania and Zimbabwe (Kapute 2017; Mussa et al. 2017) which were not found in the current study. The large percentage of female fish exporters $(86.2 \%)$ and the monthly gender differences agree with the findings from Mussa et al. (2017) that a larger number $(65.7 \%)$ of women from Malawi are involved in the informal cross border fish trade. The issue of women empowerment is therefore, crucial as $70 \%$ of women in the Southern African Development Community (SADC) are involved in the informal cross border trade (Mussa et al. 2017).

The study recommends that the Government of Malawi should make a balanced decision on policy issues regarding regulation of fish exports. This comes at a time when demand for fish on the local market in the country is not satisfied. Further, the government should consider exploring fish processing methods that ensure highest quality for exports to highly regulated markets. The more women $(86.2 \%)$ than men $(13.8 \%)$ who exported fish from Blantyre District provides insights on the unsustainability of fish exports. Therefore, a policy that considers mainstreaming of gender into the policy may ensure the sustainability of livelihoods of women in fish exports.

\section{Acknowledgements}

We thank the Malawi Government's Department of Fisheries and Blantyre District Fisheries Office for providing the data used in this study.

\section{References}

Bhattacherjee A. 2012. Social science research: principles, methods and practices. 2nd ed. Florida: Anol Bhattacherjee $159 \mathrm{p}$.

Commonwealth/GTZ. 2007. ESA meeting on trade and sustainable approaches to fisheries negotiations under WTO/EPA. Port Louis: ESA. Report No.: (07) 05.

Donda S, Njaya F. 2007. Food security and poverty alleviation through improved valuation and governance of river fisheries in Africa: Fisheries comanagement in Malawi, analysis of the underlying policy progress; [cited 2018 Jan 04]. Available from http://pubs.iclarm.net/wfcms/file/bmz/Malawi_policy .pdf.

Government of Malawi (GoM). 2011. Annual economic report 2012. Lilongwe: Ministry of Development Planning and Cooperation.

Government of Malawi (GoM). 2012. National fisheries policy 2012-2017. 2nd ed. Lilongwe: Ministry of Agriculture and Food Security.

Haambiya L, Matiya G, Msukwa A, Kapute F, Sikawa D. 2013. Factors that influence effectiveness of local organisations in promoting community participation in artisanal fisheries management in Malawi: A case of Mbenji island fishery. Malawi Aqua Fish. 2(1):1-7.

Jayalal L, Ramachandran A. 2012. Export trend of Indian ornamental fish industry. Agric Bio J North America. 3(11):439-451. doi:10.5251/abjna.2012.3.11.439.451.

Kapute F. 2009. Fish quality and processing in Malawi: Responding to challenges through institutional capacity building. Reykjavik: United Nations University Fisheries Training Programme (UNUFTP) Project Report.

Kapute F. 2017. Chasing Malawi fish: the irony of local fish scarcity versus exports. The 2017 Malawi Fisheries and Aquaculture Symposium 22 $2^{\text {nd }}$ to $24^{\text {th }}$ November 2017. Sun n Sand Holiday Resort, Mangochi. Malawi.

Manyungwa-Pasani CL, Hara M, Chimatiro SK. 2017. Women's participation in fish value chains and value chain governance in Malawi: a case of Msaka (Lake Malawi) and Kachulu (Lake Chilwa). Cape Town: Institute for Poverty, Land and Agrarian Studies. Working Paper No.: 45.

Mussa H, Kaunda E, Chimatiro S, Banda L, Nankwenya B, Nyengere J. 2017. Assessment of informal cross border fish trade in the southern African region: a case of Malawi and Zambia. Paper presented at: Malawi Fisheries and Aquaculture Forum; Mangochi, Malawi.

Singini W. 2013. Bioeconomic analysis of Chambo (Oreochromis spp.) and Kambuzi (small Haplochromine spp.) fish stocks of Lake Malombe. [PhD Thesis], University of Malawi. 199 p.

Ukaonu SU, Mbawuike BC, Uluwajoba EO, Williams AB, Ajuonu N, Omogoriota HO, Olakolu FC, Adegbile OM, Myade EF. 2011. Volume and value of ornamental fishes in the Nigerian export trade. Agr Bio J North America. 2(4):661-664. doi:10.5251/abjna.2011.2.4.661.664. 